Irina Kolbutova

Moscow

irina_kolbutova@yahoo.co.uk

\title{
FACE TO FACE AND ONE FACE REFLECTED IN MANY MIRRORS
}

In this article I would like to demonstrate how a very ancient theological concept emerged unexpectedly through the mediation of the Platonic tradition almost simultaneously in the twelfth-century Latin West and in a remote oriental context, and how these two later developments of the same set of ideas can clarify each other and their common roots.

At the outset it is worth making some observations concerning the use of the early Christian writings in this study, which scholars of the previous generations almost indiscriminately called "gnostic" thus using the term by which, as was noted by A. DeConick, they attempted to reconstruct "an umbrella religion called 'Gnosticism,' a religion which in fact did not exist." ${ }^{1}$ Furthermore, as R. G. Hall indicated, "the terms 'Jewish,' 'Christian,' and 'gnostic' are notoriously slippery when applied to texts from early in the second century. The Odes of Solomon, with their close relationship to the Hodayot from Qumran, on the one hand, and to later gnostic literature, on the other, would belong equally in studies of ancient Jewish hymnody, early Christian prophecy, and the origin of gnosticism. The Gospel of John belongs as clearly in a study of Gnostic origins as in a study of Christian origins and is Jewish to such an extent that one of the biggest issues it faces is being put out of the synagogue." ${ }^{2}$ Finally, A. Golitzin highlighted the problem noting the "re-evaluation of apocalyptic literature, Christian origins, and the analysis of Gnosticism" for which scholars "had begun to look to more proximate (as opposed to distant Iranian), Jewish sources." As this scholar observed, "we can find a striking instance of this shift in the respective - and stunningly different - analyses of the Acts of

(1) A. D. DeConick, "What is Early Jewish and Christian Mysticism?" in Paradise Now: Essays on Early Jewish and Christian Mysticism, ed. by A. D. DeConick, Leiden: Brill, 2006, pp. 12-13.

(2) R. G. Hall, "Isaiah's Ascent to See the Beloved: an Ancient Jewish Source for the Ascension of Isaiah?" JBL, 113 (1994), p. 466. 
Thomas offered by Gunter Bornkam in the early 1960s for the first edition of W. Schneemelcher's anthology, The Apocryphal New Testament, and, thirty years later, by Han Drijvers for the second edition of the same anthology, where the change in direction is practically absolute. Bornkam sees nothing but 'Gnosticism' and Iranian motifs in the apocryphon, while Drijvers barely breathes the word, 'Gnostic,' and does so chiefly in order to dismiss it and insist instead on the fundamentally Jewish-Christian character of the document, including the justly famous 'Hymn of the Pearl,' which Bornkam had seen as totally devoid of Christian elements." ${ }^{3}$ In a footnote A. Golitzin quoted H. Drijvers, who wrote about the "Hymn of the Pearl" as "one of the most beautiful products of Syriac literature."4

\section{$* * *$}

In a series of articles A. Orlov studied an interesting feature in the "Merkabah" tradition, namely, the encounter of the visionary's own self in the form of a "face." In a pseudepigraphon Ladder of Jacob Jacob beholds the divine Glory as "the Face of God." This Face appears to be as well Jacob's heavenly counterpart. Similar visions are described in the pseudepigraphical literature as referring to Moses and Enoch. ${ }^{6}$ A. Orlov highlights the importance of the theophanic role of God's Glory-Kavod in these accounts, "These features of both Enochic accounts, entertaining the idea of the heavenly twin, point to the importance of the vision of the Kavod in the process of acquiring knowledge about the heavenly counterparts of the visionaries." ${ }^{7}$

(3) A. Golitzin, "The Image and Glory of God in Jacob of Serug's Homily, 'On That Chariot That Ezekiel the Prophet Saw',' Scr, 3 (2007), pp. 182-183.

(4) Ibid., p. 183, n. 12, referring to H. Drijvers, "Introduction," in Acts of Thomas, in New Testament Apocrypha, 2nd ed., ed. by W. SCHNeEMelcher, vol. 2, Cambridge, Louisville, 2003, p. 330.

(5) A. Orlov, "The Face as the Heavenly Counterpart of the Visionary in the Slavonic Ladder of Jacob" in Of Scribes and Sages: Early Jewish Interpretation and Transmission of Scripture, vol. 2: Later Versions and Traditions, ed. by C. Evans, London, 2004, pp. 59-76.

(6) A. Orlov, "Ex 33 on God's Face: A Lesson from the Enochic Tradition," in Seminar Papers 39, SBLAM 2000, Atlanta, 2000, pp. 130-147; A. OrLov, "Moses' Heavenly Counterpart in the Book of Jubilees and the Exagoge of Ezekiel the Tragedian," Biblica, 88/2 (2007), pp. 153-173.

(7) A. OrLov, “The Face as the Heavenly Counterpart,” p. 71. 
The notion of the divine Glory is also connected with the motive of the reflection of a visionary in a mirror by St. Paul, because this

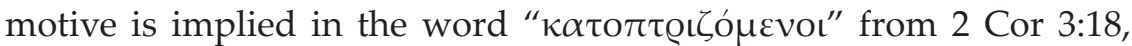
"But we all, with open face beholding <lit. "reflecting" - I. K.> as in a

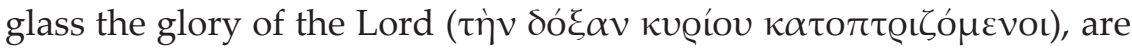

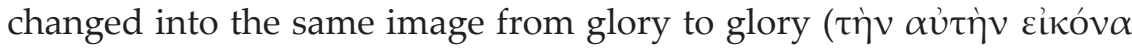

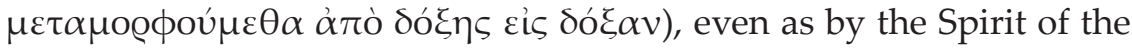
Lord." In his study of the notion of the "Glory" in this Pauline passage, P. B. Duff refers to the Apostle's experience of a personal encounter with Christ, "In 2 Cor 4:6, Paul talks about the knowledge ( $\gamma v \tilde{\omega} \sigma \iota \varsigma)$ of

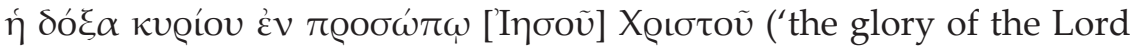
in the face of [Jesus] Christ'). As many have pointed out, Paul almost certainly refers here to his life-changing encounter with the risen Jesus (Gal 1:15-16). So, Paul seems to be saying that, at the time of his 'con-

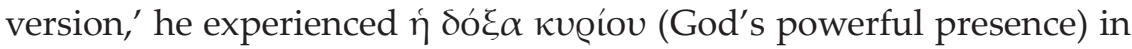
a Christophany." ${ }^{8}$ Duff interprets this $\delta$ ó $\xi \alpha$ as "the life-giving power of God as it has been manifested in the resurrection of Christ," ${ }^{9}$ while other scholars proposed an interpretation of this experience of the Apostle in terms of the merkabah mysticism. According to G. Quispel, "...the story about his experience on the road to Damascus, as told by Luke, contains some very clear allusions to the visionary experience of Ezekiel. Paul fell to the earth and heard a voice saying to stand upon his feet because he is to be sent... exactly as Ezekiel was dumbfounded, Paul was blinded after his vision. For those familiar with the meaning and purpose of such hints in ancient literature, there cannot be the slightest doubt that the author of Acts is paralleling the vocation of Ezekiel and the vocation of St. Paul. As the kabod appeared to the prophet in Babylonia in 593 BC, so the kabod appeared to Saul near Damascus in AD 32." ${ }^{10} \mathrm{~A}$. Segal also interprets Saul's vision of light in Acts 9 and 22 as a theophanic experience witnessing to the origins of the Merkabah traditions, which enables the Apostle to identify Christ with the "Glory of God." 11

(8) P. B. Duff, “'Transformed "from Glory to Glory': Paul's Appeal to the Experience of His Readers in 2 Corinthians 3:18," JBL, 127/4 (2008), p. 770.

(9) Ibid., p. 771.

(10) G. QuisPel, "Ezekiel 1:26 in Jewish Mysticism and Gnosis," VC, 34 (1980), p. 8.

(11) A. Segal, Paul the Convert. The Apostolate and Apostasy of Saul the Pharisee, New Haven, London, 1990, p. 11. 
Duff further suggests that the notion of the Glory in connection with the image of the mirror presupposes the transformation of the Christians into this Glory, "If we recognize that the participial struc-

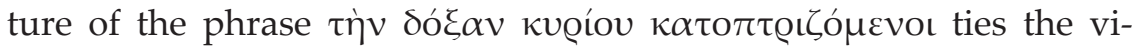
sion of God's power manifested in Christ's resurrection to the believers' transformation, then the mirror imagery functions to emphasize what is already implicit in the verse, that is, that the vision of $\eta \delta$ ó $\xi \alpha$ кu@íov represents the believers' vision of their own transformation. In other words, the believers see in themselves (i.e., 'as in a mirror') 'the glory of the Lord' as they are transformed into 'the same image,' that is, into the image of the risen Christ."12 As was discussed also by C. R. A. Morray-Jones, "in the apocalyptic-merkabah tradition the ascent into heaven and the vision of the kabod (whom Paul identifies with Christ) involves a transformation of the visionary into an angelic or supra-angelic likeness of this glory or divine image, and ...this seems to be the background of Paul's concept of "glorification" (for example, Rom 8:29; 2 Cor 3:18)." "13 Accordingly, Morray-Jones comes to a conclusion that "the 'man in Christ' is thus Paul's 'heavenly self' or 'apostolic identity,' which is conformed to the image of the enthroned and glorified Christ and therefore possesses 'power' and divinely conferred authority." 14 Thus, it seems that Paul reconstructed the Jewish background in a way that a Christian in his spiritual ascent encounters his true self in a mirror where he sees Christ as a divine Glory and in this way the heavenly twin of a Christian believer, the glorified risen Christ, appears to be a Glory of the Father, and a Christian is transformed "from Glory into Glory."

Some early Christian texts, as it seems, clearly reveal what is meant by St. Paul by the vision of Glory in the mirror.

Ode, 13 of the Odes of Solomon: Behold! The Lord is our mirror: open the eyes and see them in Him: and learn the manner of your face: and tell forth praises to His spirit: and wipe off the filth from your face: and love His holiness, and clothe yourselves therewith: and be without stain at all times before Him. ${ }^{15}$

(12) P. B. Duff, “Transformed "from Glory to Glory," p. 774.

(13) C. R. A. Morray-Jones, "Paradise Revisited (2 Cor 12:1-12): The Jewish Mystical Background of Paul's Apostolate. Part 2: Paul's Heavenly Ascent and Its Significance," HTR, 86 (1993), p. 273.

(14) Ibid.

(15) J. R. Harris, The Odes and Psalms of Solomon, Cambridge, 1909, p. 106. 


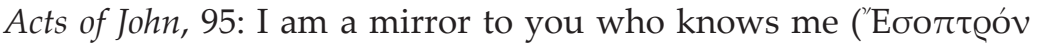

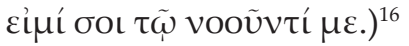

The theme of the encounter with one's heavenly twin is present also in the Christian Thomas-tradition. The Logion 84 of the Gospel of Thomas announces, "Jesus said: 'When you see your likeness, you rejoice. But when you see your images which came into being before you, and which neither die nor become manifest, how much you will have to bear!'"17 This last thought of the encounter with one's celestial Self is contained in a famous final act of the story narrated in the Hymn of the Pearl in the Acts of Thomas, 112:

But suddenly, when I saw that the robe became like a mirror, and I have seen my whole self on it, and I have realized and have seen myself through it, so that we being separated into parts of it, at the same time were one in one form.

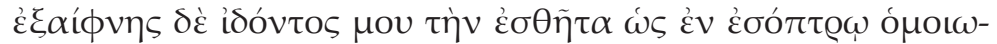

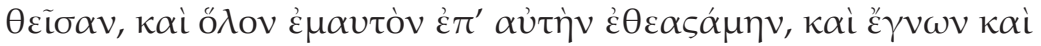

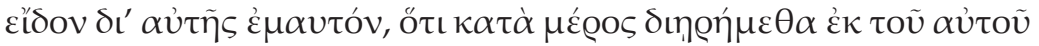

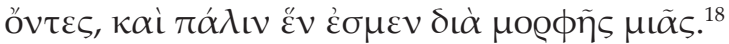

This passage, probably, represents the same combination of themes of Christ in a mirror as a Christian's heavenly twin and of the recovering of a believer's lost heavenly garment, as in the discussed earlier Ode, 13 of the Odes of Solomon.

A psychological experience described in the Hymn of the Pearl, corresponds to a similar experience, expounded by the Alexandrian philosopher Plotinus in his Enneads, V.8 [13] 11, 1-13:

Further, one of us, being unable to see himself, when he is possessed by that god brings his contemplation to the point of vision, and presents himself to his own mind and looks at a beautified image of himself; but then he dismisses the image, beautiful though it is, and comes to unity with himself, and, making no more separation, is one and all together with that god silently present, and is with him as much as he wants to be and can be. But if he returns again to being two, while he remains pure he stays close to the god, so as to

(16) Acta Johannis, 95, 12, Acta Apostolorum Apocrypha, ed. by M. Bonnet, Hildesheim, 1959, II, 1, p. 198.

(17) Trans. by T. O. Lambdin, in The Nag Hammadi Library in English, ed. by J. M. Robinson, Leiden, 1996, p. 135.

(18) Acta Thomae, 112, 9-13, Acta Apostolorum Apocrypha, ed. by M. BonNET, Hildesheim, 1959, II.2, p. 223. 
be present to him again in that other way if he turns again to him. In this turning he has the advantage that to begin with he sees himself, while he is different from the god; then he hastens inward and has everything, and leaves perception behind in his fear of being different, and is one in that higher world; and if he wants to see by being different, he puts himself outside. ${ }^{19}$

The Gospel of Thomas (Logion 22), also provides a corresponding parallel:

Jesus said to them: "When you make the two one, and when you make the inside like the outside, and the outside like the inside..." 20

In his study of the Gospel of Thomas, A. DeConick came to the conclusion that this Gospel was known to the Alexandrian Christians already in the first century and acquired there some Hermetic features. ${ }^{21}$ On the other hand, according to G. Quispel, the motive of the encounter of one's heavenly twin in the Thomas tradition explains the religious experience of Mani. This scholar wrote that "...Peterson was quite correct in pointing out that it would be difficult to explain Mani's experience with the Twin without the Acts of Thomas (in which Thomas is looked upon as Jesus's twin)..." ${ }^{22} \mathrm{He}$ adds also that "Mani was a Jewish Christian. For this reason, his basic experience, the encounter with the Self, should be explained against this background. In this case, it should, however, also be possible to understand the fundamental concepts of Manichaeism, the identity of the ego and the self, the empirical ego and the guardian angel, in terms of his Jewish Christian origin." 23

L. Sweeny, in turn, raised a question of possible connections between Mani's experience and the conception of the true "Self" in Ploti-

(19) Plotinus, Ennead V, with an English translation by A. H. Armstrong (LCL, 444), Cambridge, MA, London, 1995, p. 273.

(20) Trans. by T. O. Lambdin, in The Nag Hammadi Library in English, p. 129.

(21) A. DeConick, "The Original Gospel of Thomas," VC, 56 (2002), p. 196.

(22) G. Quispel, "The Birth of the Child: Some Gnostic and Jewish Aspects," Eranos, 40 (1971 [1973]), p. 8.

(23) Ibid., p. 16. 
nus. ${ }^{24}$ This scholar adduced the Cologne Mani Codex ${ }^{25}$ where this event in Mani's life is described in the following way:

... at the time when my body reached its full growth, immediately there flew down and appeared before me that most beautiful and greatest mirroring of [who I really am - namely, my twin] (17.1);

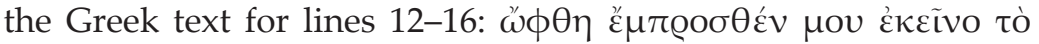

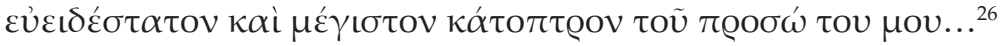

Certainly, it is dangerous to advance any suggestions without seeing the actual manuscript of the Codex, but it seems possible to ask a question of whether the better reading of the last words which puz-

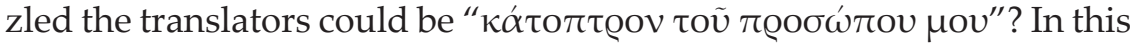
case the similarity between the notion of the true Self in Mani and the Thomas tradition can be supported by a textual reference in Plotinus, Enneads, I, 1 [53], 8, 9-19:

But how do we possess God? He rides mounted on the nature of Intellect and true reality - that is how we possess him; "we" are third in order counting from God, being made, Plato says, "from the undivided," that which is above, "and from that which is divi-

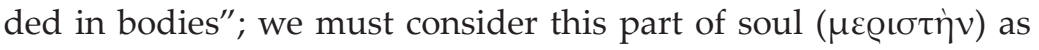
being divided in bodies in the sense that it gives itself to the magnitudes of bodies, in proportion to the size of each living being, since it gives itself to the whole universe, though the soul is one: or because it is pictured as being present to bodies since it shines into them and makes living creatures, not of itself and body, but abiding itself and giving images of itself, like a face seen in many

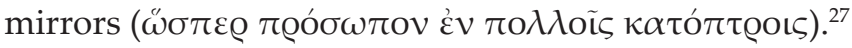

(24) L. Sweeny, "Mani's Twin and Plotinus: Questions on 'Self,'”' in Neoplatonism and Gnosticism, ed. by R. T. Wallis and J. Bregman, Albany, NY, 1992, pp. 381-424.

(25) The Cologne Mani Codex was edited with a German translation and commentary in A. Henrichs and L. Koenen, "Ein griechischer Mani-Codex," Zeitschrift für Papyrologie und Epigraphic, 19 (1975), S. 1-85; 32 (1978), S. 86-199; 44 (1981), S. 201-318; and 48 (1982), S. 1-59.

(26) Quoted in L. Sweeny, "Mani's Twin and Plotinus," p. 383 with reference to R. Cameron, A.J. Dewey, The Cologne Mani Codex (P. Colon. inv. nr. 4780): 'Concerning the origin of His Body' (Texts and Translations, 15, Early Christian Literature Series, 3; Missoula, MT, 1979), p. 19.

(27) Plotinus, Ennead I with an English translation by A. H. Armstrong (LCL, 440), Cambridge, MA, London, 1995, pp. 111-113. 
This image, as it seems, correlates with the Plotinian idea that in the human soul, its lower part is the reflection as if in the mirror of its own upper part without being cut off from it, ${ }^{28}$ for the clarification of which Plotinus refers to the myth of Dionysus and the Titans. The same mythological motive can be found in yet another context, indicated by J. Dillon, "Prof. A. Henrichs points out to me that there may be a connection between the nous which contains the forms of $\mu \varepsilon Q \iota \kappa \alpha$

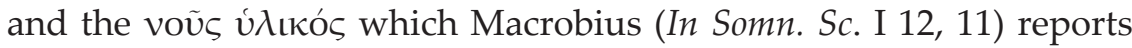
the Orphics as identifying with Dionysus. This Orphic nous projects itself from the undivided (transcendent) Nous, and divides itself among individuals (in singulos), the rending of Dionysos by the Titans being a mythological expression of this metaphysical fact." ${ }^{29}$ This remark in a footnote is made by Dillon in the context of the discussion of the doctrine of the two Intellects found in the Proclus's commentary (and attributed by Proclus to Theodore of Asine) on Timaeus 35A, "the passage where Timaeus is describing the creation of the soul from the mixture of $\eta \dot{\alpha} \mu \varepsilon \dot{\varepsilon}$

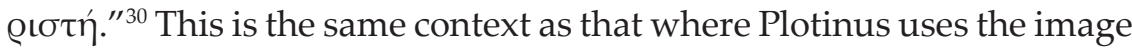
of the one face reflected in many mirrors.

In this article J. Dillon established that the problem of the two intellects is related to a difficult and much discussed problem of the ideas of the individuals. ${ }^{31}$ Recently this problem was discussed again by

(28) Cf. Enneads VI, 2 [43] 22, 28-36; IV, 3 [27] 12, 1-5.

(29) J. Dillon, "The Concept of Two Intellects: a Footnote to the History of Platonism," Phronesis, 18 (1973), p. 182, n. 5.

(30) Ibid., p. 181.

(31) Cf. "The role of the first nous, that which contains and contemplates the Ideas, hardly needs much discussion. It is the second nous whose position is open to question. Now it was always a problem in Platonism to account for the individuality of individuals. The Stoics had their doctrine of the isíws Toเóv, that quality which makes an individual unique, but the Stoics did not have problems about the intelligible world, and whether there are intelligible archetypes of individual qualities. It was this that Plotinus had to face, and what Plotinus in fact deals with in his essay 'Whether there are Ideas of Individuals' (Enn. V. 7). Not that Plotinus here makes any use of a concept of two intellects, but the sort of problem he was raising was possibly that to which this postulation of a second nous was an attempt to find an answer." (Ibid., pp. 183-184). 
P. Kalligas, 32 who wrote that "the identification between the form of Socrates and the highest part of his soul, far from being unacceptable for Plotinus, can be found as his considered opinion in several places in the Enneads. The most explicit occurrence is in the second chapter of the late treatise On What is the Living Being and What is Man (I 1 [chron. No. 53]), which, oddly enough, has been so far overlooked in discussions concerning forms of individuals. We find not only an explicit statement that 'soul is a kind of form,' but also some traces of an argument that supports it, contained in the preceding hypothesis: 'If soul and essential soulness are one and the same' (Enneads, I 1.2.6)" 33

Thus, P. Kalligas has discovered the discussion of the problem of the forms of individuals in Plotinus in the same treatise Enneads I, 1, which contains also the metaphor of one face reflected in many mirrors, and which seems to be related to the same problem. Further the same scholar came to a conclusion that "...we have to do here with three levels of manhood: one is that of the ideal archetype and another corresponds to the 'many' sensible men, but between these two there must be an intermediate level which is 'in matter' but still 'one in many... like a seal-imprint in many things.' This interpretation is confirmed by the well-known analysis of the nature of man, in the VI 7.6.9f, into a first, second and third 'man.' The first is the intelligible Form of Man, Man in itself, the second the higher, rational and noetic soul, and the third the lower projection of soul into the body, the subject of passions and sensations. The second one of these seems to be especially mobile and, although its proper residence is in the intelligible world, it may somewhat paradoxically - extend its activities as far as the bodies of animals. But 'before it is spoilt, it wills man and is man'; one might say it is the core of human existence." ${ }^{34}$ In this way, we have a threefold construction of a Man, and the quoted passage from Plotinus, Enneads, I, 1 [53], 8 can be summarized in the following way:

1. God - intellect and true reality;

2. "we" "from the undivided,"/ face;

3. "we" "from that which is divided in bodies"/ seen in many mirrors.

(32) P. Kalligas, "Forms of Individuals in Plotinus: a Re-Examination," in Phronesis, 42 (1997), pp. 206-227.

(33) Ibid., pp. 214-215.

(34) Ibid., p. 219-220. 
At the same time, one may note that for the expression of his understanding of the ideas of individuals, Plotinus has chosen a JewishChristian image-concept of the "face in the mirror," which symbolises the self of a Christian. Moreover, a striking parallel to the Plotinian

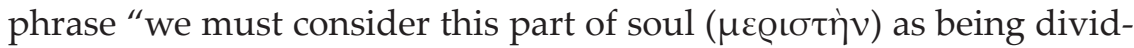
ed in bodies in the sense that it gives itself to the magnitudes of bodies" can be found in 1 Cor. 13:9-12:

For we know in part ( $\dot{\kappa} \kappa \mu \varepsilon \dot{\rho} \mathrm{g} \circlearrowleft \varsigma)$, and we prophesy in part. But when that which is perfect is come, then that which is in part ( $\tau$ ò $\dot{\varepsilon} \kappa \mu \dot{\varepsilon}$ oous) shall be done away. When I was a child, I spoke as a child, I understood as a child, I thought as a child: but when I became a man, I put away childish things. For now we see through a

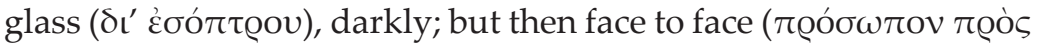

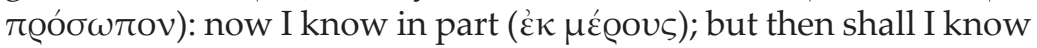
even as also I am known.

The idea of the particularity was mentioned earlier in 1 Cor. 12:27, "Now you are the body of Christ, and members in particular ( $\dot{\varepsilon} \kappa$

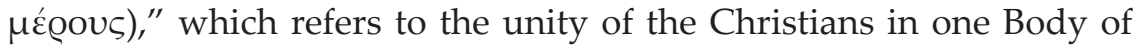
Christ: "For as the body is one, and has many members, and all the members of that one body, being many, are one body: so also is Christ" (1 Cor. 12:12).

This Pauline concept was discussed by A. G. Gottstein, who came to the conclusion that the "Rabbinic Adam myths have served as one theoretical source for the concept of body of Christ. The physical understanding of image of God in rabbinic literature may be relevant to the development of the concept of the body of Christ when we realize that Christ is both image and body." 35 This scholar continued developing his argument suggesting that "Jesus as image is also Jesus as body. As first-born Jesus restores the original zelem. The concept of image of God allows Paul to address Gentiles as well as Jews, for this image is not a natural body, but a body of the elect, that is, the church." ${ }^{36}$

Moreover, in the Pseudepigraphic literature, as it was discussed by A. Orlov, this original zelem can be represented as the "face": "It has been demonstrated that the Face in 2 Enoch 22 represents the cause and the prototype after which the new celestial identity of Enoch was 'created.' The new creation fashioned after the Face signifies here the

(35) A. G. GottsteIn, "The Body as Image of God in Rabbinic Literature," HTR, 87 (1994), p. 193.

(36) Ibid., p. 194. 
return to the prelapsarian condition of Adam, who according to the Slavonic apocalypse was also 'modeled' during his creation after the Face of God. In 2 Enoch 44:1 one can learn that the protoplast was created in the likeness of God's Face. The text says that "the Lord with his own two hands created mankind; in a facsimile of his own face, both small and great, the Lord created [them]." It is intriguing that 2 Enoch departs here from the canonical reading attested in Gen 1:26-27, where Adam was created, not after the face of God, but after His image (tselem). In view of this departure, the author of the recent English translation of the Slavonic apocalypse, Francis Andersen, observed that 2 Enoch's "idea is remarkable from any point of view... This is not the original meaning of tselem... The text uses podobie lica [in the likeness of the face], not obrazu or videnije, the usual terms for 'image.' The previous analysis, however, demonstrated that this reading does not arise in the Slavonic environment but belongs to the original argument of 2 Enoch, where the creation of the luminous protoplast after the Face of the Lord corresponds to a similar angelic 'creation' of the seventh antediluvian patriarch. There is almost no doubt that, in view of the information about Adam's glorious angelic nature attested in 2 Enoch 30:11, the author of the Slavonic apocalypse tries to connect the theme of Adam's creation with the motif of the glorious Face of the Lord." ${ }^{37}$

$$
* * *
$$

We may find an explicit joining of the conception of the "divine form" in humanity and of the Plotinian metaphor of one face reflected in many mirrors in the Latin West in the twelfth century. The two conceptions are put together in a passage from the Commentum on the De Trinitate of Boethius (Librum hunc) attributed to Thierry of Chartres (or an author belonging to his school).

Therefore, this form "Humanity" neither is nor is said to be that form which is "divinity." But the problem should be better expressed in the following way: this form, inasmuch as it in itself or inasmuch as it is a form (for, certainly, the appellation "humanity" is not applied to that which designates the admixture of matter), I say that this form or this equality of being, inasmuch as it is in itself, is a divine form; yet when the pronoun is added in the expression "this form," it does not designate any admixture of matter.

(37) A. Orlov, "'Without Measure and Without Analogy': The Tradition of the Divine Body in 2 (Slavonic) Enoch," Scr, 3 (2007), pp. 255-256. 
Just as if one face, reflected in many mirrors, is really one in itself, but, because of the variety of mirrors is supposed to be now this face, now another face, also in a similar way, if this comparison can be allowed, indeed the divine form shines in a certain way in every man, and it is no other form than this one form, inasmuch as it is in itself, which is the form of all things, if you would consider that this pure and true simplicity is supposed to be various by those who bear on themselves this form. ${ }^{38}$

The scholars who studied the doctrine of Thierry of Chartres, were aware of the Platonic nature of this metaphor, ${ }^{39}$ however, they did not indicate its origin. In fact, the metaphor of one face reflected in many mirrors was employed by Macrobius, ${ }^{40}$ whose writings were known

(38) "Forma ergo hec humanitas forma illa que est diuinitas nec est nec esse dicetur. Sed dicatur sic: forma hec quantum in se est uel in quantum forma est - humanitatis scilicet nomine quod contagionem materie designat non addito - forma inquam hec uel hec essendi equalitas quantum in se est forma diuina est ita tamen ut pronomen additum cum dicitur "forma hec" nullam contagionem materie designet.

Sicut enim facies una in diuersis renitens speculis una quidem in se est sed pro speculorum diuersitate hec una illa uero altera esse putatur ita quoque, si comparare liceat, forma quidem diuina in omnibus quodam modo relucet nec est nisi una quantum in se est rerum omnium forma si harum que forme putantur diuerse illam puram ueramque simplicitatem consideres."

(Commentaries on Boethius by Thierry of Chartres and his School, ed. by N. M. HärING, Toronto, 1971, p. 83).

(39) "There are indeed sentences in the Commentum that give the impression of a mystical monism" (P. Dronke, "Thierry of Chartres," in A History of Twelfth Century Western Philosophy, ed. by P. Dronke, Cambridge, 1988, p. 383); “In Teodorico de Chartres, una forte ispirazione eriugeniana si manifesta nella commossa visione della presenza divina, descritta nel Commentum super Boethium de Trinitate (Librum hunc) con accenti che paiono sfumare il concetto di creazione nella dialettica dell'Uno e dei molti." (P. Lucentini, Platonismo medievale. Contributi per la storia dell'erigenismo, 2nd ed., Firenze, 1980, p. 51).

(40) “...secundum haec ergo cum ex summo deo mens, ex mente anima fit, anima vero et condat et vita compleat omnia quae sequuntur, cunctaque hic unus fulgor illuminet et in universis appareat, ut in multis speculis per ordinem positis vultus unus, cumque omnia continuis successionibus se sequantur degenerantia per ordinem ad imum meandi: invenietur pressius intuenti a summo deo usque ad ultimam rerum faecem una mutuis se vinculis religans et nusquam interrupta conexio" (Comm. I. 14, 15; ed. by J. Willis, Leipzig, 1970, p. 58). 
to Thierry. However, as it was pointed out earlier, Thierry used the metaphor of the face and the mirrors as an illustration of an idea of the participation of men in the universal "form of God," while Macrobius used it in the context of the explanation of the "great chain of being." Moreover, Macrobius used the word "vultus," while Thierry used "facies," the word from the Latin translation of the Pauline letters (1 Cor 13:12 "videmus enim nunc per speculum in aenigmate; tunc autem facie ad faciem"; 2 Cor 3:18 "revelata facie gloriam Domini speculantes"), where the notion of the "face" is connected with the notion of the "mirror," and which could serve as a remote background for the Plotinian metaphor.

The Hellenistic Jewish and philosophical background of the thought of Thierry of Chartres in the quoted passage can be clarified by the way as it was summarised by G. Quispel: "Not only the Jewish mystics, but also Philo mentions a heavenly Man, whom he identifies with the Logos and sometimes calls 'Man after his (God's) image' (Conf. 146) or 'Man of God' (Conf. 41). This divine Adam is an idea, incorporeal, neither male not female, by nature incorruptible (Op.134). Here an important development has taken place. The notion of the kabod, in the Greek

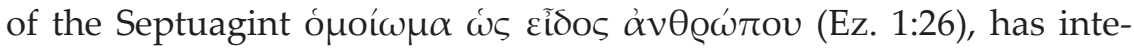
grated the Greek and platonic idea of man. Plato, the founding father of idealism, never uses this concept. It seems to occur for the first time in Seneca, Epistulae Morales 65, 7, according to whom: 'homines quidem pereunt, ipsa autem humanitas, ad quam homo effigiuntur, permanet.' According to the Middle Platonic thinker who was the source of Seneca, the idea of man is contained in the mind of God." ${ }^{41}$ It is, probably, this Seneca's "humanitas," which is evoked in the discussed passage from the Commentum of Thierry.

The terminology used by Thierry of Chartres in the passage containing the metaphor of one face reflected in many mirrors, the definition of the "forma" as the "equalitas essendi," correlates with the passage discussed by S. Gersh, for which this scholar made an attempt to find the Platonic sources: ${ }^{42}$

(41) G. Quispel, "Ezekiel 1:26 in Jewish Mysticism and Gnosis," VC, 34 (1980), p. 4.

(42) S. Gersh, "Platonism - Neoplatonism - Aristotelianism: a TwelfthCentury Metaphysical System and Its Sources," in Renaissance and Renaissances in the Twelfth Century, ed. by R. Benson and G. Constable, Cambridge, MA, 1982, pp. 512-534. 
Merito ergo ab illa simplici forma diuina rerum omnium forme emanare dicuntur quia iuxta formam illam diuinam unaqueque res suam habet essendi equalitatem. Sicut enim forma diuina equalitas essendi est sicut etiam integritas et perfectio omnium rerum ita quoque, ut ad exemplum descensus fiat, humanitas equalitas quedam et integritas essendi hominem est. Quare humanitas imago quedam forme est. Illa uero diuina uere forma est.

Rightly, then, the forms of all things are said to emanate from that simple divine Form, since besides that divine Form each thing has its own equality of being. Just as the divine Form is the equality of being and even the completeness and perfection of all things, so also, in order that there might be a descent to an exemplar, "humanity" is a specific equality and the completeness of being a man. Therefore, humanity is a certain image of form, while that divine Form is the true one. ${ }^{43}$

S. Gersh remarked that "this argument contains two striking notions which cannot exactly be paralleled in earlier medieval Platonism: first the idea that a single divine Form gives rise by an emanation to the forms of created things traditionally postulated by Platonic philosophy, and secondly the notion that this plurality of emanating forms is one not of real forms but of images." ${ }^{44}$ In order to explain these ideas, S. Gersh attributed to the author of the Commentum the combination of contradictory ideas which can be found in Latin Platonic authors, primarily Boethius and Calcidius. However, it seems clear, that the two interrelated ideas observed by Gersh are implied in the image of one face reflected in many mirrors.

As Gersh himself remarked, the Form under discussion is the constituent part of a "'certain trinity of perpetual things' (quaedam perpetuorum trinitas) descending from the highest Trinity. This turns out to be a kind of reflection of the highest Trinity in the created world, where the unity of the Father is represented by matter, the equality of the Son by the forms, and the connection of the Holy Spirit by a created spirit operating as the force responsible for the combination of matter and form." 45 This construction very much resembles the beginning of the Nag Hammadi treatise, Paraphrase of Shem. As summarized by

(43) Comm. 2. 41; Commentaries on Boethius by Thierry of Chartres and his School, ed. by N. M. HäRING, Toronto, 1971, p. 81.1-7; the translation is taken from Gersh, "Platonism - Neoplatonism - Aristotelianism," p. 518.

(44) Ibid., p. 518.

(45) Ibid., pp. 517-518. 
G. Quispel, "there was in the beginning Light and Darkness and the Spirit between them... The Spirit looked down and saw the water of Darkness. Thereupon the intellect of Darkness received an image (eine) of the Spirit, obviously mirrored in the waters of Chaos. This intellect of Darkness arose and illuminated the whole underworld (the demiurge ascends from Chaos)." 46 The Thierry of Chartres' "ad exemplum descensus" may be an echo of the Spirit's looking down, and an image (eine) of the Spirit in the waters of the Darkness may correspond to the "humanitas imago quedam forme." Moreover, in the "Tractatus de sex dierum operibus" Thierry identified the Biblical "tenebrae" with formless matter, which receives forms from the light identified with the Spirit above the surface of the abyss, ${ }^{47}$ and, as it was noted by W. Williams, in the esoteric Jewish teachings, the "pneumaticos or spiritual first Adam, born on the first day ....is associated both with the Spirit of God that hovered over the pre-mundane waters (Gen. 1:2) and, more commonly, the light of Gen. 1:3."48 The Spirit as Man, in the opinion of F. Wisse, is implied in the Paraphrase of Shem: "The position of the unbegotten Spirit between Light and Darkness is not merely spatial. It has ontological significance. On the one hand the Spirit belongs on the side

(46) G. Quispel, "The Demiurge in the Apocryphon of John," in Nag Hammadi and Gnosis, ed. by R. McL. WiLson, Leiden, 1978, p. 8.

(47) "In prima igitur die CREAUIT DEUS materiam et lucem" (Commentaries on Boethius by Thierry of Chartres and his School, ed N. M. HärInG, Toronto, 1971, p. 558); “ET SPIRITUS DOMINI FEREBATUR SUPER AQUAS. Designata materia subsequenter uirtutem artificis quam spiritum domini appellat dicit preesse materie atque dominari ut eam informet atque ordinet." (Commentaries on Boethius, p. 566); “Quoniam ergo materia informis non per se suscipit formas sed per uirtutem artificis mouentem et operantem informatur idcirco prudentissimus philosophorum Moyses post informitatem materie designatam de uirtute creatoris operatoria qua forma materie adhibetur subiunxit dicens: ET SPIRITUS DOMINI FEREBATUR SUPER AQUAS." (Commentaries on Boethius, p. 567); "ET DIXIT DEUS FIAT LUX Ostensis duobus primordiis creature, materia scilicet et uirtute operatrice, competenti ordine uult demonstrare quo modo et quo ordine SPIRITUS DOMINI in materiam operetur secundum modum in sapientia creatoris ab eterno dictum atque prefinitum. Sed in hoc loco iuxta modum expositionis de diuinitate pauca dicenda sunt ut appareat quid sit dicere dei et cur prius fecerit mentionem Spiritus quam Uerbi." (Commentaries on Boethius, pp. 567-568).

(48) W. Williams, The Shadow of God. Speculations on the Body Divine in Jewish Esoteric Tradition, <http://www.scribd.com/doc/57443803/Shadow-ofGod-Short-1>; accessed on January 4, 2013. 
of the Light over against Darkness; but it does not share the Light's incorruptibility and transcendence, for it can fall... the unbegotten Spirit functions as archetypal man, or rather as the archetype of the Semitic race, and the drama of fall and salvation, although cosmic and prior to creation, is decisive for mankind. The fall of the power or light of the Spirit is only hinted at in the document. It may have been the moment that the Spirit looked down at the dark water $(2,23 \mathrm{ff}.) . . . " 49$

On the other hand, the nature of the "holy and highest Trinity" (sancta et summa Trinitas), the reflection of which is the previously discussed "quaedam perpetuorum trinitas," is explicated by Thierry of Chartres by a mathematical method. Searching for the roots of this Trinitarian teaching, S. Gersh accepted the Augustinian source, following E. Jeauneau, ${ }^{50}$ and argued that the influence of Boethius can be also observed..$^{51} \mathrm{Nev}$ ertheless, as in the case with the use made by a Christian author of the Plotinian metaphor of one face reflected in many mirrors, which can support a hypothesis of its Jewish-Christian origin, possibly from the Thomas-tradition, the survival of this tradition in the twelfth-century author can be suggested in its elaboration by Thierry of Chartres in the shape of his famous "arithmetical proof." This can be observed by way of its comparison with an Arabic romance which is dated approximately to the thirteenth century and which presents itself as an Arabic elaboration of a Sanskrit text. This text has been wrongly attributed to Avicenna and bears the title Risâla fìl-mabdâ" wal-ma'âd ("Treatise on the origin and the return"). The fragments of this text translated into English are taken from the book of H. Corbin Inside Iranian Islam: Spiritual and Philosophical Aspects:

I lived in a country where my parents and my forebears lived. The king of this country called upon me and said: "It is fitting that you only dwell in these lofty dwellings of my kingdom after you have traveled to the lands tilled by us, alongside the farthest borders of my kingdom. Do not forget our pact of fidelity, because only then will you find me again in that faraway land. Have my minister in charge of my Threshold describe the knowledge to you, a threshold that no one can cross without such a knowledge and that can only be crossed with my permission." When I arrived at the

(49) F. Wisse, "The Redeemer Figure in the Paraphrase of Shem," Novum Testamentum, 12 (1970), p. 132.

(50) E. Jeauneau, "Mathématiques ae Trinité chez Theirry de Chartres," Miscellanea Mediaevalia, 2 (1963), pp. 298-295.

(51) Gersh, "Platonism - Neoplatonism - Aristotelianism," pp. 514-516. 
Threshold I found the minister there. I greeted him and he returned my greeting. "My Lord and my King," I said, "has ordered me to leave for the land that is tilled by us." He said: "For this voyage and in order to reach your goal, you must overcome obstacles and steep mountains and your return trip will be worse. I am afraid that because of the distance and the difficulties you might end up forgetting our pact." "Yet it is necessary that I leave," I said. "Describe that country for me and describe the way to get there." ${ }^{52}$

The place of exile is described as the city full of a crowd of active and agitated people, where he finds himself one day before the throne of the shaykh, the ruler of the country. He comes near and speaks to this shaykh: ${ }^{53}$

"I greet Thee," I said. He returned my greeting. I spoke to him and he spoke to me. Everything that I did, he did also. Everything that I said, he also said. I looked at him closely: that is me, I thought. That Shaykh is my reflected image. At once I woke up. I remembered all my promises. While I was in this bewilderment, I met the minister of my Lord, who had instructed me. He took me by the hand and said: "Immerse yourself into the Water, because it is the Water of Life." When I had immersed myself I understood the symbols and the riddles of his person. He said to me: "Welcome! You are now one of us!" He announced my return to my original home. ${ }^{54}$

When I became aware of all these questions, I discovered that the minister of my king who was very near me, was myself. The minister was my reflected image. I was utterly amazed. In this bewilderment I met the king himself. He commanded me to take a thread woven by a spider. He took the thread and split it into two, then he put it back together into one thread and said to me: "The one multiplied by the one is the One $(1 \times 1=1)$." Then I understood what he meant: I discovered that he is my soul (nafsî, my "self") and that $I$ myself am his reflected image. ${ }^{55}$

(52) H. Corbin, Inside Iranian Islam: Spiritual and Philosophical Aspects, vol. 2, Suhrawardî and the Persian Platonists, p. 204; <http://www.scribd.com/ doc/9664772/Henry-Corbins-In-Iranian-Islam-Vol2>; accessed on January 4, 2013. In the opinion of this scholar, this text is based on the story narrated in the Hymn of the Pearl from the Acts of Thomas.

(53) H. Corbin, The Man of Light in Iranian Sufism, trans. by N. Pearson, Boulder and London, 1978, p. 25.

(54) Corbin, Inside Iranian Islam..., p. 205.

(55) Ibid., p. 206. 
And now P. Dronke exposed Thierry's "arithmetical proof" in the following way: "As Thierry, like Boethius, held that in each thing its existence is inseparable from its unity, he saw unitas as an apt name for the divine forma formarum. And he was the first, to my knowledge, to use the two ways in which unitas can be said to 'generate' numbers as an image of the cosmogonic and the trinitarian process. Unity, multiplied by other numbers, engenders the entire series of whole numbers -

...but numbers are infinite, so it is necessary that unity should have no limit to its power. Unity therefore is omnipotent in the creation of numbers. But the creation of numbers is the creation of realities (rerum). So unity is omnipotent in the creation of realities... So unity is necessary deity.

On the other hand, unity can be multiplied by itself, and then the result is again unity $(\mathrm{I} \times \mathrm{I}=\mathrm{I})$ :

For unity multiplied by one is nothing other than unity. So the begetting one and the begotten one are one and the same substance, since each of them is true unity. For unity can beget nothing other than the equality of that same unity.

The Tractatus breaks off before Thierry's integumentum for the Holy Spirit, seen as the 'binding (connexio)' of equality and unity, but we can reconstruct it with the help of moments in the Boethian commentaries. The equation $\mathrm{I} \times \mathrm{I}=\mathrm{I}$, we might say, can be read in two ways: in the first, just cited, the Father, multiplying himself, brings forth the Son, who is equal to himself. But if we read it another way, we can say that the equality here affirmed proceeded (like the Spirit) from both the terms on the lefthand side of the equation, and is equal to both these terms." ${ }^{56}$

Probably, a remote model for a mathematical-and-theological construction elaborated by Thierry of Chartres was the treatise Eugnostos the Blessed (NHC III)," in which God is he "who 'sees himself within himself, like a mirror' (75.4-5)." ${ }^{57}$ According to D. M. Parrott, in this treatise the influences on Part A have been identified as Platonic/

(56) P. Dronke, 'Thierry of Chartres', in A History of Twelfth Century Western Philosophy, ed. by P. Dronke, Cambridge, 1988, pp. 380-381.

(57) A. D. DeConick, Seek to See Him: Ascent and Vision Mysticism in the Gospel of Thomas, Leiden: Brill, 1996, p. 68. 
Neopythagorean, Jewish, and Sethian. ${ }^{58}$ In addition D. M. Parrott has demonstrated the connections of this text with the Egyptian religion. According to the presentation of the doctrine of Eugnostos, made by this scholar, in this text "the first step in the development of the transcendent world occurs when this being reflects upon himself and produces a being like himself, who is appropriately called Self-Begetter, 'He who Fathered Himself,' and the like (III 75, 3-12 and par.). He has two functions: to create those who resemble him, who constitute 'The Generation over Whom There is no Kingdom among the Kingdoms that Exist' (III, 75, 17-76, 10 and par.), and bring into existence the next being, who is called Immortal Man, but also 'Begotten' or 'Begetter,' 'Perfect Mind.' He is an androgynous being, who, therefore, has a female name also, 'All-wise Begettress Sophia."'59 The pattern of these three beings, as Parrott observes, resembles a Neopythagorean scheme of Eudorus of Alexandria, "The Platonic conception of the first principles was of a monad and an indefinite dyad, with creation, i.e., differentiation, occurring when the monad interacted with the dyad. This was modified somewhat by Eudorus of Alexandria (fl. 25 B.C.) by the addition of another monad, a supreme principle, above the opposites of the monad and the indefinite dyad." 60 In addition to this Neopythagorean background, Parrot established an Egyptian theological construction with the supreme hidden and self-revealing god Amun. ${ }^{61}$

Parrott further continues his considerations in the following way: "In both Eugnostos and Egyptian religion, the second consortless deity, the direct initiator of the creative process, is a crystallization of the highest being. In the former, Unbegotten, the highest being, reflects upon himself and his image comes to appearance; this being, then, is appropriately called 'Self-Father' and 'Self-Begetter,' as mentioned above (see III 5, 3-9 and par.). In Egyptian religion, there is no one conception about who this being is." ${ }^{\prime 2}$ However, one may consider the theological conception in the so-called "Shu theology," analysed by G. Englund, "Creation is actually a reciprocal action between Atum and Shu. The coming into being of both of them depends on the oth-

(58) D. M. Parrott, "Gnosticism and Egyptian Religion," Novum Testamentum, 29 (1987), p. 81.

(59) Ibid., p. 80.

(60) Ibid., p. 84.

(61) Ibid., p. 86.

(62) Ibid., pp. 86-87. 
er. Without the potentiality represented by Atum there would be no Shu and without the differentiating faculty of Shu there would be no manifestation of Atum. The following quotation about the two crowns treats this intricate relation. One of the crowns is called the net-crown, the other the red crown. Both crowns have identical determinatives in the text, so they are actually both red crowns, like mirror images of each other. The two crowns see each other and rejoice.

I have received the net-crown on my head. The red crown rejoices when it sees the net-crown. The net-crown is on my head. The red crown is on the head of the Self-created. The net-crown will rejoice when it has seen the red crown, say the gods hearing its voice (I 387b-389a) ${ }^{63}$

On the other hand, at this point, probably, it is worth trying to explore the possible influence of what Parrott calls the "Jewish wisdom circles in the Diaspora," ${ }^{64}$ considering that the next principle has an additional female name "All-Wise Begettress Sophia," since Sophia is called the "immaculate mirror of the divine energy" in the Book of

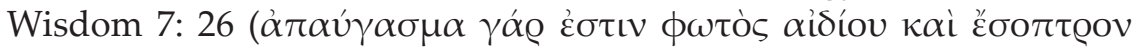

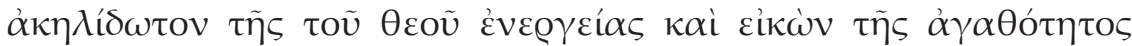
$\alpha \dot{v} \tau o \tilde{v})$. The presence of the theme of the divine light in this Scriptural reference allows us to connect it with Eugnostos 76.15-19: ("The First who appeared before the universe in infinity is Self-grown, Selfconstructed Father, and is full of shining, ineffable light") upon which A. D. DeConick commented, "Thus we find here the motif of the selfgenerated God of Light!" 65 Moreover, this motive correlates with another Nag Hammadi treatise, the Teaching of Sylvanus.

For he is light from the power of God, and he is an emanation of the pure glory of the Almighty. He is the spotless mirror of the working of God, and he is the image of his goodness. For he is also the light of the Eternal Light. He is the eye which looks at the invisible Father, always serving and forming by the Father's will. He alone

(63) G. Englund, "The Eye of the Mind and Religious Experience in the Shu Theology from the Egyptian Middle Kingdom," in "Being Religious and Living through the Eyes," in Studies in Religious Iconography and Iconology. A Celebratory Publication in Honour of J. Bergman, ed. by P. Schalk and M. Stausberg, Uppsala, 1998, p. 92.

(64) Parrott, “Gnosticism," p. 81.

(65) DeConick, Seek to See Him, p. 68. 
was begotten by the Father's good pleasure. For he is an incomprehensible Word, and he is Wisdom and Life. ${ }^{66}$

According to J. Zandee, the author of the Teachings of Sylvanus employs Jewish-Christian concepts, and in this passage almost literally repeats the previously oft-quoted definition of Sophia from the Book of Wisdom 7: 26, while the expression "he is also the light of the Eter-

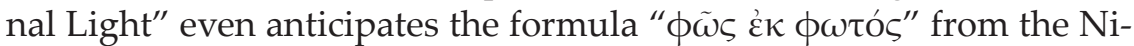
caean Creed. ${ }^{67}$

Moreover, in the earlier discussed Hymn of the Pearl, the theme of the unity-duality is elaborated, introducing the "treasure-keepers" into the narration:

And I saw the treasure-keepers themselves preparing the robe not as two, but as one form in both, and one Royal image was in both...

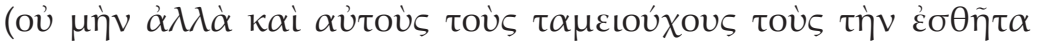

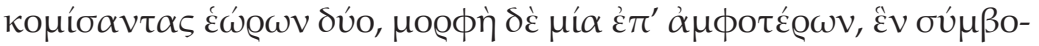

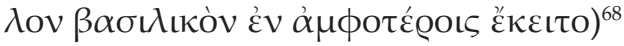

The meaning of these "treasure-keepers" can be comprehended with the help of the exegesis adduced by A. DeConick on Genesis 1.3: "4 Ezra 6.39 exegetes Genesis 1.3 as follows: 'Then you [God] commanded that a ray of light be brought forth from your treasuries...? (cp. 2 Bar. 59.11). The Light, according to this text, was not 'created' by God's command, 'Let there be light,' but rather was manifested from his light treasury which apparently existed before creation." 69 This scholar proposed this text as the background for the theology of Light in the Gospel of Thomas. The "treasure-keepers" having one Royal image in both, two and one at the same time, seem to be none other than the two monads of Eudorus of Alexandria, interpreted by the author of Eugnostos as the Supreme Deity together with its own reflection constituting the "self-generated God of Light."

(66) Trans. by M. L. Peel and J. Zandee in The Nag Hammadi Library in English, ed. by J. M. Robinson, Leiden, 1996, p. 393.

(67) J. ZandeE, “'The Teachings of Silvanus' (NHC VII, 4) and Jewish Christianity," in Studies in Gnosticism and Hellenic Religions, Presented to Gilles Quispel on the Occasion of his 65th Birthday, ed. by R. VAN DEN BROOK and M. J. Vermaseren, Leiden, 1981, p. 566.

(68) Acta Thomae, 112, 13-15, Acta Apostolorum Apocrypha, ed. by M. BonNET, Hildesheim, 1959, II. 2, p. 223.

(69) DeConick, Seek to See Him, p. 65. 
In this way, an ancient Jewish and Jewish-Christian interpretation of the experience of the encounter with the Glory in the Face of the Lord as the realization of the true celestial nature of a mystic, as it seems, reached Chartrian Platonism through the indirect mediation of the works of Plotinus who incorporated this concept into his solution for the problem of the forms of individuals in the guise of his exposition of the teaching of Plato. On the other hand, the same concept was laid as the foundation for the ancient Semitic teaching on the origin of the world as the beginning of the communication between the " $\mathrm{I}$ " and the "Self" within the Supreme Principle, which, probably, served as one of the ways for a Christian formulation of the unity-equality of the Persons of the Son and the Father.

\section{SUMMARY}

This article represents an attempt at disentangling an intricate interlace of Jewish-Christian and Platonic intellectual traditions knotted in a metaphor of one face reflected in many mirrors which can be found as early as the third century in the texts of Plotinus and as late as the twelfth century in the writings of Thierry of Chartres. This metaphor, as it seems, integrates the experience of the encounter with the true celestial nature of a mystic in the shape of the Face of the Lord. Apostle Paul presumably construed this idea in a way that a Christian believer received a privilege which had previously been reserved for the chosen Jewish Patriarchs, like Jacob, Enoch or Moses, to see his true self mirrored as Christ representing the Divine Glory. In the context of the Plotinian set of ideas, this metaphor was used to express his understanding of the ideas of individuals. In the milieu of

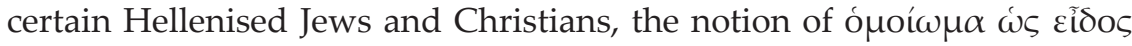

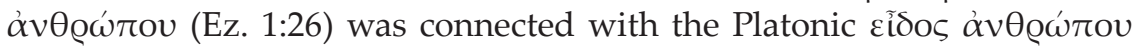
(Parmenides 130C). Moreover, the concept of the encounter of one's Self as the reflection in the mirror served for the formation of an ancient Semitic teaching where the Supreme Deity saw "himself within himself, like a mirror," which in the Book of Wisdom 7:26 was interpreted as Sophia representing an immaculate mirror of the divine energy. Thierry of Chartres used the Plotinian metaphor of one face reflected in many mirrors and elaborated a theory that the nature of a human being constituted a "certain trinity of perpetual things," reflecting the "holy and highest Trinity." For the exposition of the Trinitarian doctrine, he also invented his famous "arithmetical proof", the roots of which probably go back to a remote teaching of the Divine Monad seeing the mirror-reflection of the Divine Self in another Divine Monad. 